\title{
Culture, diversity, interculturality and cultural competence: knowledge and importance of the concepts in social work perspective
}

Recibido: 3 de octubre de 2018 / Revisado: 27 de noviembre de 2018

Aceptado: 14 de marzo de 2019 / Publicado: 22 de julio de 2019

BRACONS, HÉLIA

Instituto de Serviço Social, Universidade Lusófona de Humanidades e Tecnologias, Portugal

helia.bracons@gmail.com

http://dx.doi.org/10.24310/IJNE2.1.2019.6558

\section{RESUMEN}

Con una sociedad cada vez más globalizada y diverso en un número de áreas, es esencial para identificar los elementos clave de la diversidad cultural y para entender la diferencia, y esto es esencial para la creación de un fideicomiso a ser establecido tan mediado con los demás. El objetivo principal de este trabajo es obtener el conocimiento de los estudiantes sobre los conceptos: cultura, diversidad cultural, interculturalidad y competencia cultural y su relevancia para su formación. Los principales resultados de este estudio, realizado con los estudiantes en una Universidad de trabajo social de Lisboa permiten concluir que los estudiantes de trabajo social tienen un claro conocimiento de las nociones de cultura, diversidad cultural e interculturalidad y también la importancia de su papel en la futura práctica profesional.

Palabras Clave: Interculturalidad, competencia cultural, cultura, trabajo social.

\section{ABSTRACT}

In a more global and diversified society, it is of utmost importance to identify the main elements of cultural diversity and to understand the difference in all its dimensions in order to create, develop and mediate a trust relationship with others. The main objective of this research is to obtain information on Social Work student's knowledge about some key concepts such as: cultural diversity, interculturality and cultural competence and its relevance on their education. The main results of this study carried out with social work students of a Lisbon University shows that students do have a clear understanding about the culture concepts, cultural diversity and interculturality and are aware of the importance of interculturality in their professional future practice.

Keywords: Culture, interculturality, cultural competence, social work. 


\section{Introducción}

Cultural diversity as well as strong and close relationships between people from different cultures is a major characteristic of our time. Portugal is today more than ever, a place of cultural encounter where people share diverse origins, languages, religions, different styles of life and their histories, their identities and their experiences are daily crossed. The knowledge of these factors is crucial for social work.

Understanding culturally different groups and cultural relationships requires relevant knowledge about concepts such as culture, cultural diversity, interculturality and cultural competence. These concepts are fundamental on formation and intervention in social work.

The aim of this study is to obtain information about the knowledge that social work students have about these essential concepts.

\subsection{The concepts analysed}

\section{Culture}

Speaking about culture leads unavoidably to the definition proposed by Edward Tylor (1871:1) "Culture is a complex whole which includes knowledge, beliefs, arts, morals, laws, customs and any other capabilities and habits acquired by man as a member of society".

Tylor`s concept, broadly accepted in social sciences is intimately related with the concept of society: it is seen as the content of social actions and social systems. "Culture is the real distinctive sign of human kind" (Cuche, 1999:21). In fact, culture, as referred by Levi-Strauss, is a whole of symbols, values and views of the word that structures and makes possible human communication and enables the socialization and integration process in a given society by each new generation. Culture is what shapes us. Culture is the lens through which we evaluate everything around us: we evaluate the word through our culture (at a national, a regional, and a community or group level).

It is not only a social heritage (Linton) but a continued construction that reflects human creativity, its project of life and the capacity of adaptation. It is a whole simultaneously specific (developing the original identity of a society, community or group) and polyphonic (a sense that culture always means heterogeneity, difference, diversity).

This includes an extreme broadening of the definition of "culture" to embrace aspects of identity such as gender identity, old age identity, sexual orientation, family structure, immigration status and more. 


\section{Cultural diversity}

The idea of culture always embraces cultural diversity and cultural pluralism. Culture takes diverse forms across time and space. This diversity is embodied in the uniqueness and plurality of the group`s identities and societies making up mankind. As a source of exchange, innovation, and creativity, cultural diversity is necessary for mankind. It is a common humanity heritage that shapes present and future (UNESCO, 2002): cultural diversity widens the range of options open to everyone; it is one of the roots of human development. The 2002 UNESCO's declaration clearly emphasises the understanding of moving from cultural diversity to cultural pluralism: "in our increasingly diverse societies, it is essential to ensure harmonious interaction among people and groups with plural, varied and dynamic cultural identities as well as their willingness to live together". It also emphasises the fact that "cultural diversity presupposes the respect for human rights, i.e., that the defence of cultural diversity is an ethical imperative, inseparable from respect for human dignity "the idea that leads to the concept of interculturality as an instrument of communication and positive interaction between people and groups" (Malheiros, 2011:23).

\section{Interculturality}

Interculturality describes the need of a deep understanding and respect of all cultural expressions. And intercultural communication focuses on the mutual exchange of ideas and cultural norms and the development of deep relationships. In an intercultural society, no one is left untouched because everyone learns from each other while growing together.

This concept is, then, different from multiculturality, which refers to a society that contains several cultural groups. In this case, people live side by side, but each group does not necessarily interact with each other. Multiculturality is a reality, interculturality is a project and a policy.

Interculturality is a synonymous of cultural pluralism, i.e., with the recognition of each specific culture and the need of comprehensive interaction and mutual exchange with any other (Moreira, 1996).

It presupposes a wish to understand the difference and willingness of others, promoting new forms of cohesion on the basics of culturally different perspectives, elements and behaviours.

This does not just mean an absence of discrimination a "positive courtesy" but also the pursuit of enrichment through exchange. The recent concept of "shared identities" is a good example (Malheiros, 2011).

\section{Cultural competence}

In a broad sense, cultural competence can be defined "as the integration and transformation of knowledge about individuals and groups of people into specific standards, policies, practices and atti- 
tudes used in an appropriate cultural setting to increase relationships' quality, producing thereby better outcomes". It is the definition of NASW (2015). As a base of social work, culture competence emerged from a culturally specific practice framework and from a variety of fields. Early conceptualizations of cultural competency emerged as a response to the growing awareness and the studies on different life outcomes of minorities and marginalized communities.

Cultural competence, according to Alsina (1997) has three essential dimensions: a) cognitive, i.e., the demand for knowledge about the other and ourselves; b) affective, which it is developed mainly through empathy; c) behavioural, in the sense that the cultural competence allows the adaptation of individual behaviour of social work to the contexts of action.

A similar perspective has been adopted by Lum (2003) and by NASW (2015). In both cases, essential cultural competence elements have been categorized in three major areas: a) knowledge, generally regarding specific cultural groups; b) awareness, in the context of the practioner's own cultural identity and values, beliefs, biases and comfort level in cross-cultural situations; c) skills, which refers to the social workers ability to use appropriate methodologies and pursuit the best outcomes.

These three combined categories create a framework for what is considered as a culturally competence practice in the social work profession and other related fields.

A fourth element, referenced less frequently is the action of social justice as a part of the cultural competence framework. Action includes work on mezzo and macro levels of social work practice and education and inherently recognized power differentials in the practitioner-client relationship. Cultural competence frameworks that include action on social justice commitment change that because social work has a commitment to serving vulnerable populations and social workers must actively participate in reducing social injustice (NASW, 2015).

\section{Methodology}

This research was set out to examine the level of social work knowledge of university students about culture, cultural diversity, interculturality and cultural competence and it's relevancy in their education. The study was based on focused interviews applied to 38 Social Work students of the BA in ULHT, in October 2015. All the interviews were subject to content analysis (Bardin, 1979). 


\section{Main Findings}

3.1 Regarding the concept of culture it can be said that the majority of students interviewed shows a good knowledge of the concept. Most students (61\%) refers that this is a wide and complex notion which includes practically everything that is shared by a society or social group (E1, E2, E3, E4, E8, E9, E11, E21, E23, E24, E26, E27, E29, E30, E33, E34, E35, E36, E37 e E38).

"Culture is a complex idea but basically includes knowledge, customs, religion, arts, laws, values shared by the members of a given society" (E1)

"Culture is a way of thinking, feeling, believing as a group" (E31)

Culture is also seen by the interviewed as a social heritage.

"Culture is a whole of costumes and habits acquired since childhood, present along individual's life as part of society" (E33)

But, also, a systematic construction

"Culture is a continuous reconstruction of what has been learned" (E11)

"Culture is something that we all have and which is transmitted over time." (E28)

Culture is what makes a specific and society group

"Culture is a distinctive way of thinking and acting of a giving society" (E12)

"Culture accounts for the apparent differences between communities or groups of people" (E22).

3.2 Regarding cultural diversity "92\% of the students interviewed expressed the exchange of knowledge, customs and traditions in all societies" (E13, E16, E28).

It is "a form of enrichment for everybody" E16 and something "that must be better understood" (E29) in order to promote "a greater respect between societies, groups and individuals" (E31, E28). "Cultural diversity represents a variety of different ways of life, beliefs, behaviours, and origins" (E16).

3.3 Interculturality "is an attitude that allows understanding, comprehension and acceptance of the difference in all its dimensions" (E3, E22). This is what $74 \%$ of the students believe. For them, interculturality means "wish to respect" (E16) and, above all, "a real exchange of ideas, values and beliefs" (E9), a "mutual enrichment between individuals and groups" (E16). It presupposes "an open minded" (E6). And "it is synonymous of tolerance" (E4), the most effective way for "people to feel at home wherever it is, safe and integrated" (E19). "The idea of interculturality is essential. Promotes relationships between different groups and people and favours the cultural enrichment of our country" (E31). 
3.4 Concerning cultural competence of social workers, $63 \%$ of the students interviewed consider that it is essential to understand and work with people with different values, beliefs, customs and ways of living. For these students, a professional "must always be prepared and that implies a systematic attitude of openness to the other" (E1). "Tolerance, comprehension, empathy, capacity of adaptation" (E10) are dimensions frequently referred by the interviewed. And also "absence of prejudice and stereotypes in order to respect and understand the difference not as an obstacle but rather as a mutual enrichment" (E 13), that "promotes the adequate solution for problems that may arise" E37). Above all, a profound sense of respect for human dignity, of human rights and social justice" (E17) It is the common point between the students interviewed (71\%). "The main competence has to be the capacity of listening and observing without prejudice" (E29).

3.5 Regarding the relationship between social workers and the communities, $82 \%$ of the students consider that the relationship must be supported by an attitude of respect, tolerance, acceptance and empathy. An "open minded" is fundamental in a real professional relationship.

"A social worker must have a very close relationship with users, an intrinsic sense of respect for human rights" (E37).

"Social workers must develop an "open minded" attitude, being able to understand and accept without prejudice" (E9).

\section{Conclusions}

This preliminary research reveals a good level of knowledge among BA students of Social Work about essential concepts as culture, cultural diversity and interculturality as a decisive concepts to understand the world nowadays, the Portuguese society and as fundamental element of the framework behind the notion of cultural competence, which is recognized as a major asset of social work currently practice.

Students referred some core capacities included in cultural competence: knowledge (defined as relevant information about group history, held beliefs, values and behavioural characteristics and considered them essential to the development of a social worker competence); cultural humility (the emphases on the role of the social worker as a learner in the user-practitioner relationship); respect for other ethics and values; self-awareness (awareness of other cultures and identities in order to appreciate another person's identity); service delivery (involving the full skill use of resources, services and institutions to best assist people and communities); empowerment; communication skills; academic and professional education.

This research wishes to contribute to the development of knowledge about this subject and framework in an academic education context, including undergraduate master and doctoral programs, to 
promote the development of social workers in their professional practice, and to develop a more systematic research on this decisive subject.

\section{References}

Alsina, M. R. (1997). Elementos para una comunicación intercultural. dCIDOB, 36:11-21.

Bardin, L. (1979). Análise de Conteúdo. Lisboa: Edições 70.

Cuche, D. (1999). A Noção de cultura nas ciências sociais. Lisboa: Fim de Século.

Lum, D. (2010). Culturally competence practice. Florence, Ky. Cengage Learning.

Malheiros, J. (2011). Promoção da interculturalidade e da integração de proximidade. Lisboa: ACIDI.

Moreira, C. D. (1996). Identidade e diferença. Os desafios do pluralismo cultural. Lisboa: ISCSP/ UTL.

NASW (2015). NASW Standards for cultural competence in social work practice. Washington. DC.

Tylor, E. (1871). Primitive culture: researches into the development of mythology, philosophy, religion, art and costum. Volume 1: Universidade de Michigan.

UNESCO (2002). Declaração Universal sobre a Diversidade Cultural. 